\title{
CDR3 Spectratyping
}

National Cancer Institute

\section{Source}

National Cancer Institute. CDR3 Spectratyping. NCI Thesaurus. Code C74541.

A laboratory procedure that analyzes the genetic profile of the T-cell receptor variable complementary determining region 3 (CDR3) for an individual. The genetic sequence for CDR3 is amplified using the polymerase chain reaction and specific primers. 